By JACKSON E. TOWNE

\title{
The New Library Building at Michigan State University
}

$\mathrm{O}^{N}$ ApriL 6, 1957, the new Michigan State University Library building had been in full occupancy for one year. The structure, which has been much admired for the beauty of both its exterior and interior, is among the larger university library buildings in America. Five stories in height, including a basement or ground floor, the new MSU Library has over-all dimensions of three hundred by one hundred ninety feet, a total square footage of 216,000 , a seating capacity of 2,500 , and a volume capacity of a million plus, depending upon some use of compact shelving. This library must serve a current undergraduate enrollment of 17,000 and a graduate enrollment of 3,800 . Over one hundred doctorates in more than fifteen fields are now granted annually at MSU. The total volume count of the Library now exceeds 700,000 , including 300,000 documents. At present there is a full-time staff of more than seventy persons operating under an annual budget of more than $\$ 700,000$.

Some of the new MSU building articles were only issued locally. The plans were published with others by the ACRL Building Committee, after the Committee's first building institute; and a short illustrated article appeared in the back pages of a "building" number of the $\mathrm{Li}$ brary Journal. There have also been a brief account of the moving of the books in the Wilson Bulletin and a summarized description of the building, well il-

Mr. Towne is librarian, Michigan State University. lustrated, in the equipment-slanted Pioneer, published by Remington Rand. Selections from an early address on divisional reading room libraries by a visiting speaker in 1948, the dedicatory address in 1956, and a reprint of a post mortem paper on the plans were issued in special numbers of the News of the Friends of the MSU Library.*

From the first we felt that MSU's new library should be designed with several open-shelf reading rooms, "divisional" in scope, whatever the service costs might amount to. (Before moving in, twentytwo full-time persons were added to the staff, involving a single total salary increase of more than $\$ 100,000$.)

We asked Ralph Ellsworth of the State University of Iowa Libraries to visit our campus in May, 1948, and he spoke on the University of Colorado Li-

\section{* BIBLIOGRAPHY ON THE NEW MSU LIBRARY BUILDING}

(With the exception of items 1 and 5 , the articles here listed were written by the author of this article. Copies of items $1,5,6$, and 7 are available on request.) 1. "The University . . Library as a Teaching Instrument." By Ralph Ellsworth. News of the Friends of the Library of Michigan State College, Vol. 5, Nos. 3 \& 4; Summer-Fall, 1948; pp. 3-7.

2. "Michigan State College Library, East Lansing." ACRL Monographs. No. 4; Fall, 1952. Proceedings of the First Library Building Plans Institute; pp. 12-19; $57-62$.

3. "Function Dictated Design." Library Journal. Vol. 77, No. 22; Dec. 15, 1952; pp. 2149-52.

4. "Continuous Service in Michigan."Wilson Library Bulletin. Vol. 31, No. 3; Nov., 1956; pp. 263-64. 5 ."The University Library in Transition." $\mathrm{By}$ President John S. Millis, Western Reserve University. (Dedication Address.) News of the Friends of the Library of Michigan State University, Vol. 11, No. 2; Fall, 1956; pp. [1]-8.

6. "What We Did and Why We Did It." News of the Friends of the Library of Michigan State University, Vol. 11, No. 2; Fall, 1956; pp. 9-14. (Reprinted from the Proceedings of the First Midwest Academic Library Conference . . . May 18-19, 1956; pp. $42-47$.

7. "Reading Use Increased from First Day in New Library at Michigan State." The Pioneer. Library Bureau Division, Remington Rand. Vol. 19, No. 5; Sept.-Oct., 1956; pp. [3-7]. 
brary before a faculty club luncheon and on the plans for the State University of Iowa library at a Friends of the Library dinner the same evening. While both of these addresses were ice-breaking and dynamic and were well received, the second of the two talks included a number of details regarding special facilities and services in the University of Iowa Library somewhat far afield from the common denominator in divisional reading room practice as found today in such new library buildings as those at Washington State College, at Oklahoma A. and M. College, at the University of Georgia, or in the Lamont Library at Harvard.

When we began planning at East Lansing, we could not count on any special funds for the preparation of selected collections for our divisional rooms, as was possible at Colorado, at Nebraska, and in the Lamont Library at Harvard. The use of slashed cards in the public catalog had been discontinued at Colorado and did not appeal to us, though we found the cards working satisfactorily at Georgia. We felt committed to the use of block assignments from our Dewey classification in starting our rooms off, with selection based on books likely to be most frequently consulted. We assumed that considerable weeding before any extended period of occupancy would help reduce the inevitable pressure for expansion which would soon be experienced in all the rooms.

An unsatisfactory experiment with open stacks for freshmen for a two-year period in our old building led us to feel that we had better start with closed stacks adjoining the rooms and allow the success of the open shelves in the rooms to justify a later all-out opening to undergraduates, as was initiated in the new Wayne University Library building, for instance.

We were advised (at Nebraska) to eliminate all reference service except through our divisional rooms, but we "retained" a small general reference room on the first floor, with the desk extended out into the main lobby as close to the public catalog as possible. Our old official catalog was broken up to serve for author catalogs in the rooms, and divisional shelf lists were prepared by a four-month all-out effort immediately after moving in. We had been using a divided public catalog, and this was maintained in the new Remington Rand trays.

In the initial planning, we started with the idea of subject areas roughly divided by major Dewey classes, as at Western Reserve, but we thought of going down from the top with the earlier classes, instead of up from the bottom. A study of circulation pressures on our books turned our interest to enrollment pressures on them, and soon we were committed to college divisions, the major academic units of our university. Space considerations prevented ultimate consistency in this matter. (We wanted some room; we never yearned for the flexibility of an empty street-car barn.)

The conventional assemblage of the major university fields of knowledge under three divisions: the humanities, the social sciences, and science, was not an easy arrangement to plan for at MSU because of local peculiarities of curriculum nomenclature. A single course in our Basic College that had formerly been called History of Civilization was changed to Humanities, and so we felt that this word could not readily be applied to an entire divisional reading room. Likewise, at MSU, history is placed academically in a college division of the social sciences. As planning progressed, our humanities room ended up with the designation of Social Science and Literature.

Next we might mention that at MSU our departments of economics and political science function within our College 


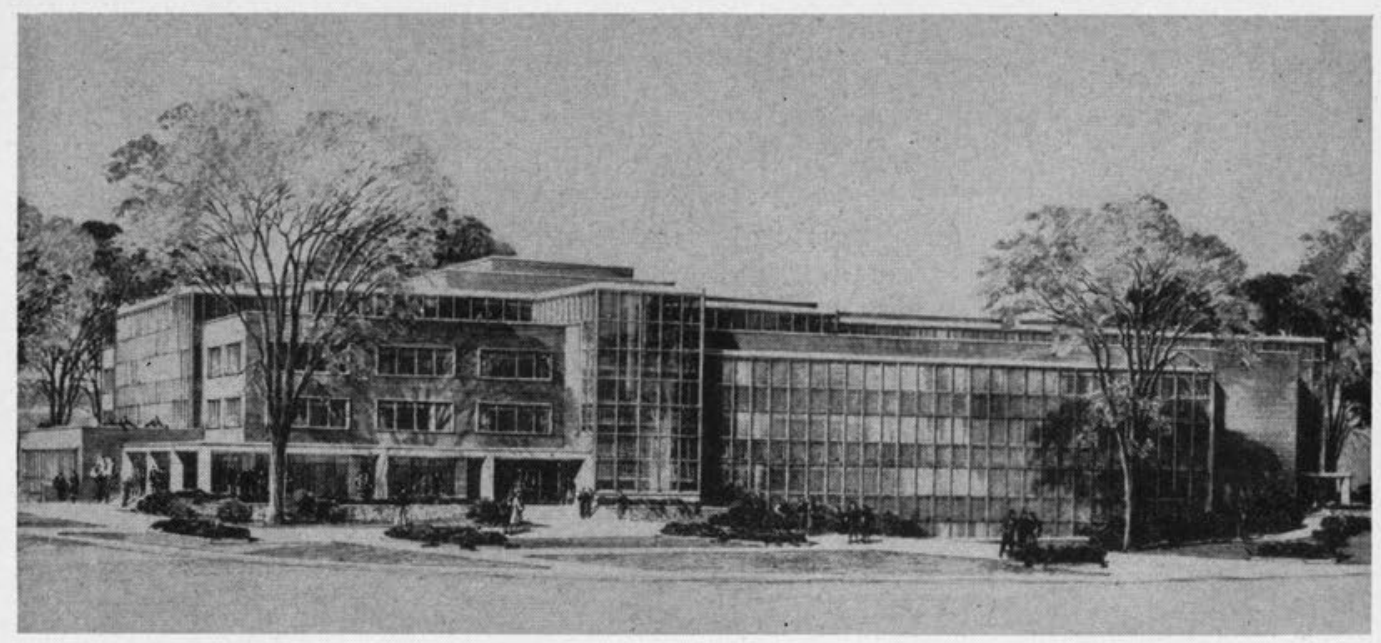

New Michigan State University Library Building (Architect's Drawing)

of Business, a college which also includes our School of Social Work. Within the limits of the Dewey decimal system it was easy to divide social science and institutions, and to assign the latter class to the collections in our Business and Public Service Room, with the field of insurance appropriately included.

Since we started with both an Educacation and a Fine Arts room, it was easy to lift the books for sports, which classify under amusements in the 700's, for shelving in Education for primary use by students in physical education. This was not possible at Washington State, for instance, where neither Education nor Fine Arts have separate rooms.

In dividing biological and physical science, we were able to assign agriculture, home economics, and veterinary medicine to the former and engineering to the latter, surely a logical arrangement. The heavy use of books in micro-biology in the Natural Science course in our Basic College necessitated our opening a section of the stacks adjoining our Biological and Applied Science Room, involving us in an inconsistency.

Biography and American and English fiction were separately shelved on the ground floor because of the special sim- plicity of the call numbers, and in the general interest of dispersal. Biography we hope to absorb into the divisional rooms by reclassification in the course of time.

Recently, in November, 1956, authorization came from our State Board providing sufficient funds to permit a change-over from Dewey to the Library of Congress classification, within a period of ten years.

The use of the LC classification for current acquisitions was begun almost immediately, and the reclassification, which will be handled in one divisional reading room at a time, now awaits the addition of professional catalogers. As the rooms are "done over," the shelving arrangements will automatically change for the better, of course.

If the stacks are to be thrown open, and we believe this change can now be made with little difficulty from the faculty, a reshelving can be achieved at once which will answer objections to certain separations of subject matter. At present, "criticism" in English literature is shelved in the stacks, while "essays" are located in the reading room, for instance.

Reserve books are issued at present from closed shelves, over counters located 
in the corridors on the second and third floors. We felt that our rooms were too large and our enrollment too extensive to attempt reserved service from the rooms, a conspicuous feature of divisional reading room practice in some libraries. The service on two separate floors was projected primarily in the interest of dispersal, to shorten lines and reduce bottlenecks. The architect drew in the unique reserve book counters, or assigned reading desks in one of his early sets of plans, and we accepted his notion.

It has been suggested that an openshelf, union reserve book room, with service organized somewhat like that in Russell Hall at Teachers College, would eliminate the short lines which do form in front of our Assigned Reading counters at certain peak hours. We can adapt our bound general periodical room on the ground floor for service as described above without the expenditure of an additional penny for equipment, and it is probable that this change will be made next August. The fact that we can contemplate it without thought of additional cost is striking proof of the flexibility of our building.

To sum up, then, and describe formally, the Michigan State University library contains six large divisional reading rooms on the first, second, and third floors, with open-shelf collections averaging 25,000 volumes each. Current periodicals are shelved in the rooms. The stacks on the first, second, and third floors contain the books likely to be less frequently called for in the subject fields represented in the adjoining divisional rooms. The stacks are open to faculty and graduate students but are closed to undergraduates, and are serviced from the circulation desk on the first floor, adjoining the main lobby. Graduate student and faculty desks are located on all three floors of the stacks. Reserved books are serviced from closed shelves at counters in the corridors on the second and third floors. A bound general periodical collection, U. S. and U. N. documents, biography and fiction, and certain specialized agencies such as a highway traffic safety library, a micro-text room, a binding preparations area, a rare-book vault, and a book-storage area are located on the basement or ground floor. At present the fourth floor contains only a lecture-room with a total seating capacity of two hundred and an attractively furnished library staffroom with kitchen attached. The six major divisional reading rooms, as designated at present, are: Social Science and Literature (first floor); Education, Business and Public Service, and Fine Arts (second floor); Biological and Applied Science, and Physical Science and Engineering (third floor). Our collections had always been largely centralized in our old building. Outside departmental libraries for Agricultural Engineering, Chemistry, and Physics-Mathematics existed and are continuing, being gradually reduced to so-called "working" collections. There is also a library for the College of Veterinary Medicine, developing from a former Bacteriology Library.

From the day we began moving into the new structure, on January 13, 1956, our students used it readily and with much ease. We moved into one divisional reading room at a time, completing the transfer of books by April 6 .

On June 30, 1956, when some of our rooms had been in operation but three months, our annual circulation showed an increase of over ten thousand volumes. This was, of course, not counting the thousands of books browsed amongst daily on open shelves during our spring term, books formerly consulted by undergraduates only through the charging system at the old main circulation desk.

A Freshman course in MSU's Basic College known as Communication Skills requires a long investigative paper in the winter term and this provides a comprehensive introduction to the use of the li- 
brary. The paper is a veritable dissertation! In February, 1956, we had moved the books into our Social Science and Literature room before the investigative paper was started, and as books were added daily in other rooms we were able to offer at least half of the most frequently consulted books in Communication Skills in the new building. The paper was completed in about five weeks, with about half of the essential volumes still issued from the main circulation desk in the old building. At this writing (early January, 1957) the investigative paper for more than four thousand freshmen has yet to be written entirely under the new roof. From the first, it has been hoped that each freshman in Communication Skills will largely confine his or her citations in the investigative paper to materials on the open shelves of only one of our six major areas.

The new MSU library is equipped with fifty faculty desks, each with two columns of separately lockable drawers, so that two assignments may be made to each desk. In 1952, plans showed that these desks would be located in partitioned offices on the library's fourth floor, but the funds for the partitions and for finishing the fourth floor were cut; so the desks were distributed throughout the stack areas on the first, second, and third floors. When the desks were announced as available, one hundred faculty applicants appeared, including certain "key figures" and one dean! The subsequent use of the desks, however, has not been impressive.

It was planned to have a hundred graduate desks located close to the windows in the stack areas, each desk equipped with three lockers, to permit triple assignments. Sun-shades for the windows in the stack areas were among last-minute items cut, and so temporary locations of the graduate desks under the ordinary stack light fixtures, rather than under the special ones prepared at the edges of the windows, became necessary. The less satisfactory lighting arrangements largely account for the as-yet limited popularity of the graduate desks. Some window shades have been received and the entire number is on order, and when they can be installed the graduate desks will be moved into alignments originally contemplated for them. At the present time about half of MSU's graduate students work half time, and some students in the scientific fields are naturally not interested in having desks in the library stacks.

We have spoken frankly of two features of the MSU Library service where popularity has yet to develop. It has been carelessly said of our building that it is undergraduate-slanted, but Michigan State's Library will certainly not succeed if it does not continuously justify its recent election to the Association of Research Libraries. Collections must be acquired for research in many fields. The administration at MSU has made generous increases to the book budget in every recent year, and this will continue.

In the meantime, the divisional reading rooms are thronged daily with thousands of students. The monthly circulation in Education has doubled, from the use of the 370's in the old building. Having followed a general principle in modern university library operation already well established at a number of wellknown universities and colleges, we have always taken the ultimate success of our planning for granted, and have not troubled to collect any special supporting data.

When we first presented our plans at Ohio State in 1952 we were asked if it would be possible for us "to return to the traditional, conservative, or whateveryou-call-it plan" (meaning to revert to the "traditional type" of library with closed stacks and a main or single circulation desk). Before we could answer, Harvard's then librarian was on his feet 
to exclaim that henceforth no library to serve as large an enrollment as Michigan State's can ever be "conservatively" planned. "You have to have several areas. Whether you call it divisional or not is not the main factor. . . ."

We recently received a letter concerning the new MSU library building from a retired expert in public library building planning and we quote the following:

"It seems to me this has all the best features of a lot of recent buildings including the all-over ceiling lighting and the air of openness and brightness which pervade the whole building. I like also the way your main floor is efficiently laid out, with the service operating center close to the main entrance and people filtering back through the specialized reading rooms, each of which has its own collection of books. To me this is an ideal relationship. . . .

"There is a lot to be studied and learned from what you have done there, and having been interested in college as well as public library buildings for a good many years, I thought I would tell you that I think it is swell . . . when I see something good I can't help getting up and cheering."

\section{Audio-Visual Activities}

(Continued from page 198)

librarian or library association committee in collecting data about audio-visual activities in American colleges and universities. The discussion strongly suggests that very little reliance can be placed on generalizations based upon the two surveys undertaken thus far by the ACRL Committee on Audio-Visual Work.

The two surveys were not necessarily intended to be comparable, the one in 1952 having been primarily concerned with discovering what patterns of audiovisual services had emerged, while the one in 1955 focussed upon size of holdings and expenditures. The results of both, however, suggested that, in general, the larger the academic institution, either the larger the audio-visual commitment, or else the greater the chance that the institution had some audio-visual facilities.

The 1955 survey found the median to be zero for answers to all questions, since the majority of respondents either left the answers blank or else inserted a zero. However, for each question asked, there were a few libraries that reported either large expenditures (several spending \$30,000 or more per year) or large holdings ( 1,000 or more films, filmstrips, slides, recordings, or pictures). The paucity of such responses, however, made it appear that only a very small percentage of American academic institutions had developed adequate audio-visual services.

Good progress has been made by certain libraries in adding audio-visual materials to their collections, but the incompleteness and incorrectness of responses secured in the two surveys makes it obvious that the full picture has not yet been obtained. It is to be hoped that the impact of these two surveys and of the present discussion may spur librarians to keep the kind of records that will enable them to supply accurate and complete data to future surveyors. 